\title{
Comment on: A trial of a mechanical device for the treatment of blepharospasm
}

\author{
Jonathan A. Go ${ }^{1}$ Ashley N. Anderson ${ }^{1} \cdot$ Ashwini Kini ${ }^{2} \cdot$ Bayan Al Othman ${ }^{2} \cdot$ Andrew G. Lee $^{1,2,3,4,5,6,7}$
}

Received: 21 May 2019 / Accepted: 18 September 2019 / Published online: 4 October 2019

(c) The Royal College of Ophthalmologists 2019

\section{To the Editor:}

Fantato et al. reports a mechanical methodology for blepharospasm treatment [1]. We report a case of Apraxia of Eyelid Opening (AEO) treated with apraclonidine, the first case of its kind in the English ophthalmic literature, which could indicate a pharmacological alternative.

A 72-year-old, Caucasian male with benign essential blepharospasm presented with a 1-year history of bilateral, simultaneous, passive ptosis and impaired voluntary eye opening. His eyes would stay open if manually opened or if he tapped his check. Botulinum toxin injections improved symptoms, but the effect dissipated after several weeks. There was no evidence of myasthenia gravis, including fatigability or orbicularis weakness, neurogenic ptosis, or third nerve palsy.

These authors contributed equally: Jonathan A. Go, Ashley N. Anderson

Andrew G. Lee

aglee@houstonmethodist.org

1 Baylor College of Medicine, 1 Baylor Plaza, Houston, TX 77030, USA

2 Department of Ophthalmology, Blanton Eye Institute, Houston Methodist Hospital, 6550 Fannin St, Houston, TX 77030, USA

3 Departments of Ophthalmology, Neurology, and Neurosurgery, Weill Cornell Medicine, 1305 York Ave, New York, NY 10021, USA

4 Department of Ophthalmology, University of Texas Medical Branch, 700 University Blvd, Galveston, TX 77555, USA

5 University of Texas MD Anderson Cancer Center, 1515 Holcombe Blvd, Houston, TX 77030, USA

6 Texas A\&M College of Medicine, 8447 Bryan Rd, Bryan, TX 77807, USA

7 Department of Ophthalmology, The University of Iowa Hospitals and Clinics, 200 Hawkins Drive, Iowa City, IA 52242, USA
His medical history was significant for obstructive sleep apnoea, coronary artery disease, and peptic ulcer disease. Surgical history included cataract extraction in both eyes (OU), LASIK, chronic dry eye, and blepharoplasty OU. Medications, family history, and systems review was non-contributory. Examination revealed best corrected visual acuity of 20/20-2 in the right (OD) and $20 / 20$ in the left (OS). Pupils measured $4 \mathrm{~mm}$ in dark and $2 \mathrm{~mm}$ in light $\mathrm{OU}$, with no relative afferent pupillary defects. External exam showed difficulty with initiation of eyelid opening OU (Fig. 1a). Intraocular pressure was $16 \mathrm{~mm} \mathrm{Hg}$ OU. Ishihara colour plates were 14/14 OU. Slit lamp and fundus examination were noncontributory.

One drop of apraclonidine $0.5 \%$ was applied OU, with improvement was noted OU (Fig. 1b). No adverse effects have been reported, and long-term efficacy will be evaluated at the next appointment.

The pathophysiology of AEO, a non-paralytic, nonblepharospasm related, motor disorder that inhibits voluntary eyelid opening, may involve supranuclear levator palpebrae muscle inhibition [2], which can be counterinhibited by botulism therapy [3]. Apraclonidine, a selective $\alpha 2$ receptor with weak $\alpha 1$ affinity, may stimulate $\alpha 1$ receptors in the levator muscle, overriding the overactive

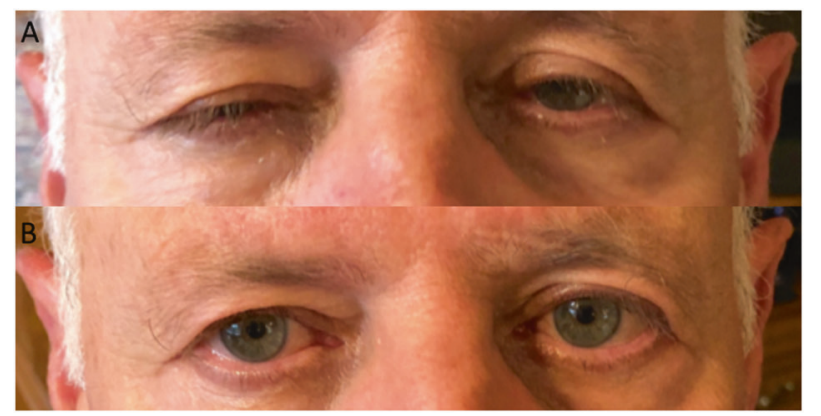

Fig. 1 a External exam showed difficulty with initiation of eyelid opening in both eyes (OU). b One drop of apraclonidine $0.5 \%$ was applied OU, with improvement was noted OU 
pretarsal orbicularis activity responsible for AEO [4]. We propose apraclonidine stimulation of the inhibited levator muscle to reverse of AEO, comparable to reported apraclonidine treatment for ptosis [5].

Further study is needed to validate this treatment. However, if a trial of apraclonidine produces improvement while in clinic, we suggest apraclonidine could be offered as therapy.

\section{Compliance with ethical standards}

Conflict of interest The authors declare that they have no conflict of interest.

Publisher's note Springer Nature remains neutral with regard to jurisdictional claims in published maps and institutional affiliations.

\section{References}

1. Fantato A, Elston J, Parulekar MA. Trial of a mechanical device for the treatment of blepharospasm. Eye. 2019. In Press.

2. Fuß G, Spiegel J, Magnus T, Moringlane JR, Becker G, Dillmann $\mathrm{U}$. Improvement of apraxia of lid opening by STN-stimulation in a 70-year-old patient with Parkinson's disease. A case report. Minim Invasive Neurosurg. 2004;47:58-60.

3. Boghen D, Tozlovanu V, Iancu A, Forget R. Botulinum toxin therapy for apraxia of lid opening. Ann NY Acad Sci. 2002;956:482-3.

4. Skibell BC, Harvey JH, Oestreicher JH, et al. Adrenergic receptors in the ptotic human eyelid: correlation with phenylephrine testing and surgical success in ptosis repair. Ophthal Plast Reconstr Surg. 2007;23:367-71.

5. Wijemanne S, Vijayakumar D, Jankovic J. Apraclonidine in the treatment of ptosis. J Neurol Sci. 2017;376:129-32. https://doi.org/ 10.1016/j.jns.2017.03.025. 